\title{
Effect of A200 super absorbent polymers on corn growth and yield under Partial Root-Zone Drying Irrigation
}

\author{
M. Sakaki, A. Shahnazari*, M.A. Gholami \\ Sari Agricultural Sciences and Natural Resources University, Water Engineering Department, Iran
}

Corresponding author E-mail: aliponh@yahoo.com

Received: 10.07.2020. Accepted: 10.08.2020

\begin{abstract}
Optimum use of consuming water in agriculture sector is one of the most major and effective solutions to cope with water crisis. Therefore, deficit irrigation is stated as a proper solution in water limitation aiming to maximally use water volume unit. Application of saving soil moisture techniques together with irrigation management increase the irrigation efficiency and promote sustainable agriculture. We considered that usage of super absorbent polymers contribute to optimal use and preservation of water resources. Our study was conducted during two growth seasons within 2014-2015 in the farm and in Sari University of Agricultural Sciences and Natural Resources on single cross 704 silage maize. The treatments included three irrigation regimes (as the main plot) and three levels of super absorbent (as subplots) with three replications. Irrigation treatments consisted of complete and partial root irrigation in two levels of 55 and 65\% (PRD65, PRD55) and three levels of water super absorbent polymer of A200 type, including 0 , 30 and $60 \mathrm{~kg} / \mathrm{ha}$. The plants, that were regularly irrigated during their growth period and cultivated with $60 \mathrm{~kg} / \mathrm{ha}$ of super absorbent, had the highest yield but they were not significantly different from plants, irrigated with 55 and $65 \%$ water volume. Thus, super absorbent reduced the irrigation volume and made possible to generate the same yield with water use 35 and $45 \%$ lower.
\end{abstract}

Key words: Deficit irrigation; maize; super absorbent; water productivity

\section{Introduction}

With an average precipitation of $250 \mathrm{~mm}$ per year, Iran is considered as arid and semi-arid areas of the world (average annual precipitation in Asia is almost $600 \mathrm{~mm}$ whereas the global is $840 \mathrm{~mm}$ ). About $90 \%$ of available water is used in agriculture sector. The rate of agriculture wastewater in Iran is $28-30 \%$, while the global average is reported as 9-12 \% (Tardio, 2005). On the other hand, in terms of climate, Iran is located in arid and semi-arid area. Due to the high need of water for domestic and industrial sectors and the necessity to achieve self-sufficiency in agricultural production, water problem and withdrawal growth should be considered regards agriculture productivity (Alizadeh et al., 2009).

Maize cultivation has a close compliance with arid and semi-arid regions in the world due to its particular features such as being C4 and especially high temperature tolerance. In arid and semi-arid areas, the optimum high crop yield could be accessed by adequate moisture requirement. With appropriate weather diversity, is the prone for maize production areas of Iran while two third of farming lands in Iran are located in semi-arid areas, practically facing with drought stress. Water shortage affects the growth and allocation of dry material and grain yield during each phase of maize growth but the rate of damage depends on time of stress, intensity and duration of water shortage (Lak et al., 2006, Rafeii et al., 2013). Since water shortage is one of barriers in successful production of this product, numerous studies have been conducted about the reasons of maize yield reduction in moisture stress conditions (Stear et al., 2001). Across all, maize (Zea mays L.) is the most widely grown globally due to ideal features and is ranked next to wheat and rice, which has been increasing in Iran over the recent years (Nourmohammadi et al, 2001). Providing ideal conditions, especially sufficient water in growth period, in arid and semi-arid areas is a serious problem.

One of the most important and effective solutions of coping with water crisis is efficient use of water in agriculture sector. In the other word, increasing "agricultural water productivity" is unavoidable in future planning and decision making as an effective factor. Therefore, deficit irrigation is stated as a proper solution in water limitation aiming to maximally use water volume unit. Deficit irrigation is not a method of irrigation but it is considered as a kind of efficient and dynamic management of exploitation, will majorly affect water resources management and ultimately agriculture economy (Kapsis et al., 1989).

In addition to applying irrigation management methods, to save soil moisture and consequently increasing irrigation efficiency, developed techniques such as using super absorbent polymers can be used. Super absorbent is a hydrophilic polymer with a three dimensional grid, capable of absorbing and maintaining high amount of water and water solutions (Behbahani et al., 2005). These materials absorb and maintain water at more than several times its own weight and environment dryness lead to evacuate gradually the moisture outside. Accordingly, keeps soil wet more without re-watering (Woo et al, 2008). Other advantages of super absorbent, increasing water penetration in soil, soil structure sustainability and reducing soil erosion, reducing the rate of evaporation from soil surface, increasing water use efficiency, increasing germination strength, increasing plant yield and reducing the need of irrigation water can be derived (Lentz et al., 1998; Teyel and EL-Hady, 1981). These properties are of major importance for coping with low water level and reducing severe water stress on plants. 
In the arid regions, super absorbent hydrogels are also claimed to increase water as soil amendment and prevent water deficiency and so, the less deficiency, the faster and healthier growth of plants especially in very hot and dry condition.

Ghasemi and Khoshkhoy (2007) evaluated the effect of super absorbent polymer on irrigation and growth of Chrysanthemum according to several morphological indicators; the majority of them were related to treatment of $8 \mathrm{~g}$ polymer in 2 -day irrigation period. In the treatments of 1 to $6 \mathrm{~g}$ polymer in 4-day irrigation, the means did not have significant difference with control treatment (without polymer) in 2-day irrigation. Karandish et al. (2012) investigated the effect of root partial deficit irrigation and ordinary deficit irrigation of maize on nitrate absorption and leaching potential, and revealed that reducing the depth of irrigation water significantly reduced leaf nitrogen and total saved nitrogen in aerial organs in the treatments of $\mathrm{DI}_{75}, \mathrm{DI}_{55}$ and $\mathrm{PRD}_{55}$ at the level of 5\%, while this difference was not significant between treatments of FI and $\mathrm{PRD}_{75}$. The rate of product yield in treatments of $\mathrm{DI}_{55}, \mathrm{DI}_{75}$ and $\mathrm{PRD}_{75}$ were less than FI treatment respectively as 54,52 and $17 \%$ in 2010 and 26,14 and $20 \%$ in 2011. This difference wasn't significant between treatments of FI and $\mathrm{PRD}_{75}$. As a conclusion, it was stated that PRD 75 method, for maintaining both environmental and economic issues, is considered as an appropriate solution to achieve sustainable agriculture.

The results of investigating the effect of super absorbent on sugarcane growth showed that using 15-25 kg super absorbent per hectare reduces the amount of irrigation for $50 \%$ and increases the amount of product and produces pure sugar for 10 to $30 \%$. The application of super absorbent in maize increases the product yield, improves the effectiveness of nitrated fertilizer and increases biomass production compared to the control group. It was also identified that using super absorbent increases growth pace uniformly from germination to full maturity of product. The application of dry super absorbent (micro) as $10-15 \mathrm{~kg} / \mathrm{hectare}$ simultaneously with cultivating the seed in rain-fed and irrigated wheat cultivation not only increases water efficiency but also increases plant establishment and yield due to providing favorable conditions for germination (Naderi and Farahani, 2006). The results of studies also showed that by promoting and improving the status of soil aggregates, maintaining soil structure, reducing soil apparent specific weight, increasing and strengthening porosity status, providing soil moisture, increasing soil penetrability and increasing the rate of water penetration in the soil, super absorbent polymers reduces or even stops erosion and runoff. High capacity of polymer water absorption leads to pores more increase and capillarity effect (Zeinoaddin and Aldakhel, 2006; Moslemi et al., 2011).

Considered the Iran's climate, lack and uneven of rainfall distribution in growing season, the current study has been conducted to investigate the effect of super absorbent polymers on soil moisture maintenance and irrigation efficiency in combination with deficit irrigation and partial root zone drying.

\section{Materials and methods}

Our study was conducted during two growing seasons of 2014 and 2015 in research farm of Sari Agricultural Sciences and Natural Resources University on single cross 704 silage maize. The soil in the experiment plots was clay loam (Table 1).

Table 1. The properties of experiment location soil.

\begin{tabular}{lllllllll}
\hline Clay, \% & $\begin{array}{l}\text { Silicate, } \\
\%\end{array}$ & Sand, \% & $\begin{array}{l}\text { Soil } \\
\text { pattern }\end{array}$ & $\begin{array}{l}\text { Nitrogen } \\
\text { percentage }\end{array}$ & $\begin{array}{l}\text { Phosphorus } \\
\mathbf{m g} / \mathbf{I}\end{array}$ & $\begin{array}{l}\text { Potassium } \\
\mathbf{m g} / \mathbf{I}\end{array}$ & EC & pH \\
21 & 29.8 & 49.2 & Loam & 0.01 & 72.5 & 600 & 2.45 & 7.3 \\
\hline
\end{tabular}

The split-plot was used as randomized complete block with three irrigation regimes (as the main plot) and three levels of super absorbent (as sub-plots) with three replications. Irrigation treatments were include full and partial root deficit irrigation at two levels of $55 \%$ and $65 \%$ (PRD65, PRD55) and three levels of water super absorbent polymer of A200 type, including 0, 30 and $60 \mathrm{~kg} / \mathrm{ha}$ (see Table 2 for details).

Table 2. Physicochemical properties of A200 super absorbent polymer.

\begin{tabular}{lc}
\hline Appearance & White granule \\
Grain size $(\mathrm{mm})$ & $0.5-1.5$ \\
Water content $(\%)$ & $3-5$ \\
Density $\left(\mathrm{g} \mathrm{cm}^{-3}\right)$ & $1.4-1.5$ \\
$\mathrm{pH}$ & $6-7$ \\
$0.9 \% \mathrm{NaCl}$ osmolarity & 45 \\
Tap & 220 \\
Water osmolarity & 190 \\
Distilled water osmolarity & 7 \\
Appearance & 7 \\
\hline
\end{tabular}

Cultivation was performed in the middle of May with the row space in maize cultivation of $75 \mathrm{~cm}$ and plant distances $20 \mathrm{~cm} \times 7 \mathrm{~cm}$ in the row. Water requirement of full irrigation treatment was calculated based on equation 1. In partial root irrigation, $55 \%$ and $65 \%$ of water volume from complete irrigation were applied.

$$
I_{n}=\sum_{i=1}^{n}\left(\left(\Theta_{F c}-\Theta_{w}\right) \times D_{i}\right)
$$

Where $I_{n}$ is water requirement in millimeters, $\theta_{F c}$ is the volume percentage of farm farming capacity, $\theta_{w}$ is the volume percentage of soil moisture before irrigation, $D_{i}$ is the depth of each layer in millimeters and also $\mathrm{i}$ is the number of each soil layer.

To provide water requirement of plant, the drip tape irrigation system was used. In partial root irrigation, we set two laterals on both sides of cultivation row, $20 \mathrm{~cm}$ for each cultivation row on the ground. This is ensured that water flow periodically only in one of them to provide the dryness of other root side. Whereas in full irrigation systems, there were also two lateral pipes on both sides of cultivation row, which both simultaneously irrigated in these treatments. To measure the soil moisture and determine the irrigation time, time domain reflectometry (TDR) was used. Irrigation was conducted aiming to moisturize root according to the field capacity. The volume of irrigation water was also recorded by flow meter for all treatments. 
To investigate the variations and methods of moisture distribution in soil, three pipes of 1 meter of TDR device were installed vertically on cultivation row and between two laterals. To this end, moisture data in the $20 \mathrm{~cm}$ depths scope on cultivation row and between drip tape and cultivation row were daily read and recorded. Two days irrigation interval was considered.

The irrigation water use efficiency (IWUE) was calculated for different treatments by equation 2.

$$
\text { IWUE }=\frac{Y}{I_{n}}
$$

Where $Y$ is equal to product yield and $I_{n}$ is the net depth of irrigation which were calculated from equation 1.

During the growth period and after applying the treatments in four phases, the leaves area index, wet and dry weight of stem and leaf were measured. To determine grain yield and biomass at the end of growing season, the middle rows were sampled through eliminating side, beginning and ending rows of each plot and total weight of aerial organs was measured using digital scale. Leaf, stem and grain samples related to each treatments were separately put in the ventilated oven at $70{ }^{\circ} \mathrm{C}$ for 72 hours. Then sample dry weight was measured by digital scale. The data were analyzed in SAS v. 9.1 software in factories arrangement based on complete randomized block and the means of treatments were compared through LSD test at $5 \%$ level.

\section{Results and discussion}

The results of the paired sample t-test showed that for most crop parameters, there was a significant difference at the level of $5 \%$. The results of variance analysis showed that main effects of irrigation levels and the application of super absorbent were significant on the ear diameter traits, ear length, ear weight, tassel weight, ear leaf area, the number of ear, grain number in ear, thousand weight, biomass, total yield per hectare and harvest index (Table 3). The variance of irrigation and super absorbent effect the maize yield and yield component.

Table 3. Irrigation and super absorbent effect on maize yield and yield components.

\begin{tabular}{|c|c|c|c|c|c|c|c|c|c|c|c|c|}
\hline $\begin{array}{l}\text { Change } \\
\text { resources }\end{array}$ & $\begin{array}{l}\text { Degrees } \\
\text { of } \\
\text { freedom }\end{array}$ & $\begin{array}{c}\text { Ear } \\
\text { diameter } \\
(\mathrm{cm})\end{array}$ & $\begin{array}{c}\text { Ear } \\
\text { length } \\
(\mathrm{cm})\end{array}$ & $\begin{array}{c}\text { Ear } \\
\text { weight } \\
\text { (g) }\end{array}$ & $\begin{array}{c}\text { Tassel } \\
\text { weight } \\
\text { (g) }\end{array}$ & $\begin{array}{c}\text { Ear } \\
\text { leaf } \\
\text { area } \\
\left(\mathrm{cm}^{2}\right)\end{array}$ & $\begin{array}{c}\text { Ear } \\
\text { number }\end{array}$ & $\begin{array}{c}1000 \\
\text { grains } \\
\text { weight } \\
\text { (g) }\end{array}$ & $\begin{array}{l}\text { Grains } \\
\text { per ear }\end{array}$ & $\begin{array}{c}\text { Biologic } \\
\text { yield } \\
\text { (kg/ha) }\end{array}$ & $\begin{array}{c}\text { Grain } \\
\text { yield } \\
\text { (kg/ha) }\end{array}$ & $\begin{array}{c}\text { Cultivation } \\
\text { index }\end{array}$ \\
\hline Replication & 3 & 1.678 & 14.27 & 5.05 & 0.154 & 492 & 0.09 & 1748.42 & 2651.65 & 161.17 & 5671.3 & 289.501 \\
\hline Irrigation & 2 & $1.844^{* *}$ & $18.865^{*}$ & $7.32 * *$ & $0.18^{\mathrm{ns}}$ & $791 * *$ & $0.1752^{* *}$ & $1073^{\mathrm{ns}}$ & $3347.3 * *$ & 171.99* & $3693.7^{*}$ & $306.122 * *$ \\
\hline $\begin{array}{l}\text { Super } \\
\text { absorbent }\end{array}$ & 2 & $1.99 * *$ & $7.525^{* *}$ & $9.334 *$ & $0.9 * *$ & $503 * *$ & $0.86^{* *}$ & $\underset{\mathrm{ns}}{1504.2}$ & $4278.25^{* *}$ & $68.87^{* *} *$ & $1235.2^{*}$ & $134.28 * *$ \\
\hline $\begin{array}{l}\text { Super } \\
\text { absorbent } \\
\text { irrigation* }\end{array}$ & 4 & $0.326 *$ & $0.18^{* *}$ & $2.584^{*}$ & $0.2^{\mathrm{ns}}$ & $334^{\mathrm{ns}}$ & $0.127^{*}$ & $25.25^{\mathrm{ns}}$ & $35.69^{n s}$ & $0.416^{\mathrm{ns}}$ & $181.7^{\mathrm{ns}}$ & $10.956 * *$ \\
\hline Error & 17 & 0.9 & 0.59 & 9.747 & 0.1 & 24.07 & 0.39 & 0.1 & 56.68 & 0.452 & 812 & 0.536 \\
\hline $\begin{array}{l}\text { Changes, } \\
\%\end{array}$ & - & 6.9 & 4 & 9.1 & 2.45 & 12.4 & 9.29 & 13.7 & 15 & 15 & 5.4 & 4.1 \\
\hline
\end{tabular}

$*, * *$ are respectively significant values at confidence level of $5 \%$ and $1 \%$

When the plants are fully irrigated and supplied with $60 \mathrm{~kg} / \mathrm{ha}$ of super absorbent, the crop parameters increased in contrast to irrigation levels (Table 3). In Table 4, the different level of irrigation with different volume of super absorbent is showed. In $55 \%$ irrigation, the lowest harvest index was registered towards control treatment and $65 \%$ irrigation. We also determined the maximum harvest index $(37.5 \mathrm{~kg} / \mathrm{ha})$ with $60 \mathrm{~kg} / \mathrm{ha}$ of super absorbent. We also found that under the treatment without super absorbent the maize had the lowest harvest index $(26.4 \mathrm{~kg} / \mathrm{ha})$. Nevertheless, the application of $30 \mathrm{~kg} / \mathrm{ha}$ of super absorbent did not have a significant effect on harvest index (27.6 kh/ha) regards control. Sridhara (2018) reported that applying water stress in different phases of maize growth shows that water stress in ear and formation phase cause severe reduction in grain yield. Applying water stress in growth stage will also decline by $28-32 \%$ the produced dry matter. In case of stress treatment during the flowering, yield reduced that lead to disorder in grains inoculation due to drying of upper leaves and male flowers. Water stress at grains filling stage, leads to shrunken grains with small weight affecting current plant photosynthesis capacity, assimilates amount and shortens the length of grains filling period.

Table 4. Comparing effect of irrigation levels and super absorbent on maize yield traits.

\begin{tabular}{|c|c|c|c|c|c|c|c|c|c|}
\hline $\begin{array}{l}\text { Harvest } \\
\text { index } \\
(\%)\end{array}$ & $\begin{array}{c}\text { grain yield } \\
\text { (kg/ha) }\end{array}$ & $\begin{array}{c}\text { Biologic } \\
\text { yield } \\
\text { (kg/ha) }\end{array}$ & $\begin{array}{c}\text { Grain } \\
\text { number } \\
\text { per ear }\end{array}$ & $\begin{array}{c}\text { Ear } \\
\text { number } \\
\text { per plant }\end{array}$ & $\begin{array}{c}\text { Ear leave } \\
\text { area } \\
\left(\mathrm{cm} / \mathrm{m}^{2}\right)\end{array}$ & $\begin{array}{c}\text { Ear } \\
\text { weight } \\
\text { (g) }\end{array}$ & $\begin{array}{c}\text { Ear } \\
\text { length } \\
\text { (cm) }\end{array}$ & $\begin{array}{c}\text { Ear } \\
\text { diameter } \\
(\mathbf{c m})\end{array}$ & $\begin{array}{c}\text { Irrigation } \\
\text { levels }\end{array}$ \\
\hline $35.7 a$ & $9356 a$ & $31.56 a$ & $472.3 a$ & $1.44 a$ & $391.3 a$ & $0.187 a$ & $17.93 a$ & $2.5 a$ & Control \\
\hline $31.19 c$ & $9087 c$ & 29.92b & 438.7c & $1.17 b$ & $352.6 c$ & $0.153 c$ & $16.73 c$ & $2.11 \mathrm{c}$ & $55 \%$ \\
\hline $33.87 b$ & $9145 b$ & $31.01 a$ & $448.6 b$ & $\begin{array}{l}\text { 1.3a } \\
\text { Super ab }\end{array}$ & $\begin{array}{l}367.6 \mathrm{~b} \\
\text { sorbent }\end{array}$ & $0.174 b$ & $17.4 b$ & $2.478 b$ & $65 \%$ \\
\hline $26.4 c$ & $7089 c$ & $24.33 c$ & $416.8 c$ & $1.17 c$ & 339.9b & $0.132 c$ & $15.29 \mathrm{c}$ & $2.14 c$ & 0 \\
\hline $27.64 b$ & $7773 b$ & $27.67 b$ & 438.1b & $1.4 b$ & 349.1b & $0.153 b$ & $16.59 b$ & $2.478 \mathrm{~b}$ & 30 \\
\hline $37.5 a$ & $10968 a$ & $32.33 a$ & $454.7 a$ & $1.78 \mathrm{a}$ & $394.1 \mathrm{a}$ & $0.186 a$ & $18.30 \mathrm{a}$ & $2.814 a$ & 60 \\
\hline
\end{tabular}

*The means, having similar letters in one column are significantly different from each other based on Duncan multi-thread test at confidence level of $5 \%$.

Allahdadi and Moazenghamsari (2006) investigated the effect of four A200 water super absorbent polymer (0, 100,200 and 300 $\mathrm{kg} / \mathrm{ha}$ ) and three irrigation intervals (5, 7 and 9 times a day) on single cross 704 silage maize growth and yield under farm conditions. Their experiments showed that increasing the height and yield of maize is obtained by using high values of super absorbent. They also reported that there is no significant difference between the product of 3-day irrigation interval without polymer and 7-day irrigation interval with $200 \mathrm{~kg} /$ hectare polymer. Jandaghian (1996) showed that by increasing the value of Polyacrylamide 
Polymer in cultivation environment of philodendron from zero to $50 \%$, the plant length, leaf number, leaf surface, wet and dry weight of shoot and root dry and wet weight increased. Ghasemi and Khoshkhouy (2007) reported that super absorbent polymer had a positive and significant effect on the indicators of leaf number and leaf area in dry stress conditions.

According to the importance of water use efficiency, Todler reported that using anionic Polyacrylamide Polymer in sand and loam soils increased water maintenance. Taylor and Halfacre (1986) also reported that new leaf growth in improved hydrophilic polymer and hydrophilic polymers need far less irrigation than those, have been cultivated in the environments without polymer. Moslemi et al. (2011) observed that by increasing the values of hydrogel super absorbent, the soil water maintenance significantly enhanced and after stopping irrigation, the lifelong of Pinus halepensis treated with $4 \%$ of hydrogel super absorbent was two times higher.

The analyzing variance results of mutual irrigation effects and super absorbent showed that mutual effects of irrigation levels and the application of super absorbent had significant effect on the traits of ear diameter, ear length, ear weight, ear number, and harvest index (Table 5).

The plants, irrigated regularly during their growth period and cultivated with $60 \mathrm{~kg} / \mathrm{ha}$ of super absorbent, had the most rate of yield traits but they did not have significant difference with the plants, irrigated with 55 and $65 \%$. We assumed the function of super absorbent in these treatments increased the efficiency of water use and partial irrigation in 55 and $65 \%$ volume that has been able to generate an equal yield with the conditions of complete irrigation. Super absorbent saves water, improves physical conditions and probably appropriate accessibility to nutrients, and increases the dry material yield through saving water and releasing it at the right time.

Our research also proved that super absorbent polymers increased plant's accessibility to moisture and consequently improved irrigation efficiency through absorbing and maintaining irrigation water and releasing it gradually. In the conditions of Iran, using the super absorbent polymers is highly recommended and it could be an ideal method for optimum use of precipitation, soil moisture maintenance, and increase irrigation efficiency.

Table 5. Comparing the mutual effect of irrigation intensity and super absorbent on ear diameter, weight, number and cultivation index

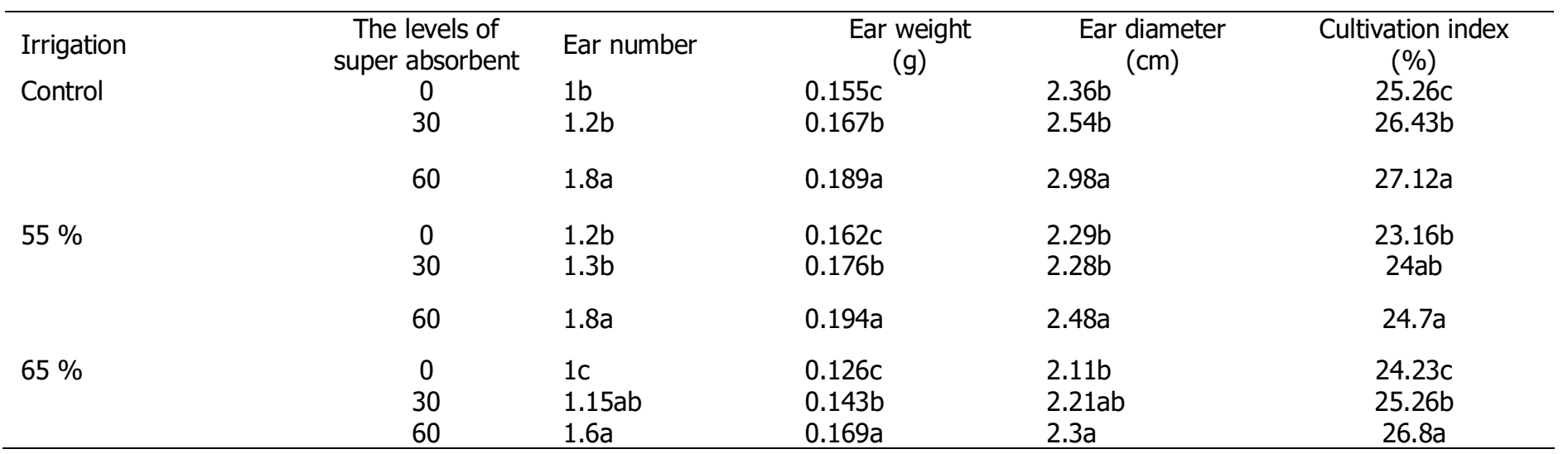

The means, having similar letters in one column are significantly different from each other based on Duncan multi-thread test at confidence level of $5 \%$.

\section{Conclusion}

We established that super absorbent polymer mostly focus on infiltration function as major part of irrigation system. We confirmed the efficiency of the suggested super absorbent by improving the soil aggregates, increased plants accessibility to moisture, enhanced irrigation efficiency, and the total maize yield and harvest index exceeding $60 \mathrm{~kg} / \mathrm{ha}$ and $37.5 \%$ respectively.

\section{References}

Alizadeh Oghyanous, P., Azari A., Salimi M. (2010). Studying the reaction of grain yield of lines and maize hybrids to the interaction of moisture stress and nitrogen fertilizer amounts. First National Conference on Environmental Tensions in Agricultural Sciences. Birjand University

Allahdadi A., Moazzen Ghamsari, B. (2006). Investigating the effect of different levels of SuperABA-200 polymer and different levels of irrigation on growth and yield of forage maize. Proceedings of the third specialized educational period for agricultural and industrial applications of super absorption hydrogels, Tehran, Iran

Behbahani, S.M.R., Mashadi, R., Rahimi Khoub A., Nazarifar, M.N. (2006). Investigation the effect of Stockosorb super absorbent polymer on drop irrigation moisture onion and physical properties of soil. Irrigation and Drainage Journal of Iran, (1)3, 98-100.

Ghasemi M., Khoshkhouy M. (2008). Investigating the effect of superabsorbent polymer on irrigation interval and growth and development of garden chrysanthemum. Journal of Iranian Gardening Science and Technology, 8(2), 65-82

Jandaghian M. (2017). Investigation the effect of Polyacrylamide Copolymers on Philodendron scandans S. and Pelargonium hortorum L. Master's thesis for gardening, Islamic Azad University, Jahrom Unit.

Kipis, T., Vaisman, I., Granoth, I. (1989). Drought stress and alfalfa production in Mediterranean environment. Irrig Sci. 10, 113-115 Karimi A. (1994). Investigating the Effect of the IGT Amendment on some physical properties of soil and plant growth. Master's thesis, Faculty of Agriculture, University of Tehran

Lentz, R.D., Sojka, R.E., and Robbins, C.W. (1998). Reducing phosphorus losses from surface-irrigated fields: Emerging polyacrylamide technology. Journal of Environmental Quality, 27, 305-312.

Moslemi Z., Habibi D., Asgharzadeh A., Ardakani M. R., Mohammadi A. and Sakari A. (2011). Effects of super absorbent polymer and plant growth promoting rhizobacteria on yield and yield components of maize under drought stress and normal conditions. African Journal of Agricultural Research, 6(19), 4471-4476. 
Naderi K.Sh., Siadat A., Aeineh A.A., Nourmohammadi Gh. (2007). Effect of different levels of nitrogen and plant density in different moisture conditions on Yield, yield components and efficiency of consumption of single cross 704 silage maize in Khuzestan. Journal of agricultural sciences of Iran, 8, 153-170.

Naderi, F., Farahani, A.V. (2007). Maintaining soil moisture by using water absorbing polymers (hydrogels). Journal of soil and water sciences, 20(1),

Noormohammadi Gh., Siadat A., Kashani A. (2002). Agriculture. Vol. 1. Shahid Chamran University Press, Ahwaz.

Rafiei, F., Nourmohammadi, G., Chokan, R., Kashani, Ali., Haidari Sharif Abad Houssein. (2013). Investigation of superabsorbent polymer usage on maize under water stress. Global Journal of Medicinal Plant Research, 1(1), 82-87.

Setter, T.L., Brian, A., Lannigan, F., and Melkonian, J. (2001). Loss of kernel set due to water deficit and shade in maize: carbohydrate supplies, abscissic acid and cytokinins. Crop Science, 41, 1530-1540.

Sridhara Sh. (2018). Growth and yield of rainfed maize as influenced by application of super absorbent polymer and Pongamia leaf mulching. International Journal of Chemical Studies, 6(5), 426-430

Tardieu, F., Reymond, M., Hamard, P., Granier, C., Muller, B. (2000). Spatial distributions of expansion rate, cell division rate and cell size in maize leaves: a synthesis of the effects of soil water status, evaporative demand and temperature. J. Experim. Botany, $51,1505-1514$.

Teyel, M.Y., El-Hady, O.A. (1981). Super gel as a soil conditioner. Acta Horticulturae, 119, 247-250.

Taylor, K.C., Halfacre, R.G. (1986). The effect of hydrophylic polymer on medi water retention and nutrient availability to Ligustrum lucidum .J. Hort. Sci, 21,1159- 1161.

Wu L., Liu M., Liang L. (2008). Preparation and properties of a double-coated slow-release NPK compound fertilizer with superabsorbent and water retention. Bioresource Technology, 99,547-554

Zeineldin, F.I., Aldakheel, Y.Y. (2006). Hydrogel polymer effects on available water capacity and percolation of sandy soils at AlHassa, Saudi Arabia. CSBE/SCGAB 2006 Annual Conference.

\section{Citation:}

Yatsenko, V., Ulianych, O., Yanowskiy, Y. (2020). Effect of A200 super absorbent polymers on corn growth and yield under Partial Root-Zone Drying Irrigation. Ukrainian Journal of Ecology, 10(4), 1-5.

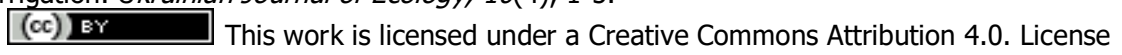

